\title{
O lugar do intérprete de Libras em escolas da rede estadual do sul de Minas Gerais
}

\author{
Gabriela Serenini Prado Santos Salgado* \\ Universidade Vale do Rio Verde
}

Recebido em:31/05/2019

Aceito em: 29/11/2019

\begin{abstract}
Resumo: Este artigo se propõe a apresentar a análise do discurso de uma intérprete de Libras, inserida na rede pública estadual de MG, a partir dos estudos bakhtinianos, estudos Surdos e sociolinguísticos da linguagem. A pesquisa qualitativa interpretativista, situa-se no escopo da Linguística Aplicada e possui viés etnográfico. Seu corpus é formado por recortes de uma entrevista semiestruturada realizada no ano de 2018, na cidade de Varginha/MG. A pesquisa mostrou que as funções do intérprete de Libras, dentro das escolas da rede estadual no sul de Minas Gerais, ainda não estão definidas e causam a desvalorização do profissional.
\end{abstract}

Palavras-chave: Intérprete de libras. Língua brasileira de sinais. Análise do discurso. Ideologia linguística.

\begin{abstract}
This article proposes to present the discourse analysis of an interpreter of Libras, located at a public school in the Minas Gerais state, from the Bakhtin's studies, studies about the deaf community, and sociolinguistic studies of language. The qualitative interpretativist research is within the scope of Applied Linguistics and has an ethnographic bias. Its corpus is formed by parts of a semi-structured interview conducted in 2018, in the city of Varginha/MG. The research showed that the functions of the interpreter of Libras, within the state schools in the south of Minas Gerais, are not yet defined and cause professional demerit.
\end{abstract}

Keywords: Interpreter of Libras. Brazilian sign language. Speech analysis. Linguistic ideology.

Zusammenfassung: In diesem Artikel soll die Diskursanalyse eines Libras-Dolmetschers vorgestellt werden, der in das staatliche öffentliche Netzwerk von MG aufgenommen wurde und aus den Studien zu Bakhtin, Gehörlosen und soziolinguistischen Sprachen stammt. Die qualitative interpretativistische Forschung ist im Rahmen der Angewandten Linguistik angesiedelt und ethnographisch ausgerichtet. Sein Korpus besteht aus Teilen eines halbstrukturierten Interviews, das im Jahr 2018 in der Stadt Varginha / MG durchgeführt wurde. Die Untersuchung ergab, dass die Dolmetscher-des-Funktionen von Libras in den Schulen des staatlichen Netzwerks im Süden von Minas Gerais noch nicht definiert sind und die berufliche Abwertung verursachen.

Schlüsselwörter: Dolmetscher von "libras". Brasilianische Gebärdensprache. Diskursanalyse. Sprachliche Ideologie. 


\section{Introdução}

Vivemos em um país que carrega, tradicionalmente, uma cultura ouvinte monolíngue cercada por outras tantas culturas linguísticas que são ignoradas pelos próprios cidadãos brasileiros. Oficialmente, o Brasil é regido por duas línguas oficiais: a Língua Portuguesa e a Língua Brasileira de Sinais (Libras). Neste sentido, são vários os participantes desse cenário linguístico, no qual se inserem ouvintes, surdos, surdos-cegos e intérpretes de Libras.

O embate que existe entre as línguas orais e as Línguas de Sinais é denso e histórico. A Libras configura o surdo para longe do quadro patológico e o insere em uma sociedade igualitária, o que significa, segundo Gesser (2009, p. 10), que a legitimidade da Libras "desvia a surdez como deficiência - vinculada às lacunas na cognição e no pensamento - para uma concepção da surdez como diferença linguística e cultural” (GESSER, 2009, p. 10).

A pesquisa considera a língua no seu contexto social e ideológico. Bakhtin (Volóchinov) (2012, p. 99) afirma que a "língua, no seu uso prático, é inseparável de seu conteúdo ideológico ou relativo à vida" portanto, nada mais relevante do que pesquisar a língua de sinais em seu ambiente social e as contribuições relevantes que surgem neste campo de estudo.

A pesquisa realizada se situa no escopo da Linguística Aplicada (doravante LA), tendo em vista o comprometimento com uma produção de conhecimento que seja responsiva à vida e ao envolvimento do diálogo entre diversas áreas do saber e diferentes modos de produção do conhecimento. Por isso, articula uma perspectiva de língua como fato discursivo à visão de linguagem advinda dos estudos bakhtinianos. Nesse escopo, será discutido o mito do monolinguismo no Brasil e a questão das Línguas de Sinais como língua minoritária. Em reconhecimento ao fato de que áreas do saber diferentes da Linguística podem ter muito a nos dizer sobre a ação constitutiva da linguagem no mundo social, apresentamos também a perspectiva dos estudos sobre surdez. A construção do corpus, cuja análise aqui se apresenta, foi realizada por meio de entrevista coletada individualmente "que combina perguntas abertas e fechadas, onde o informante tem a possibilidade de discorrer sobre o tema proposto" (BONI; QUARESMA, 2005, p. 75).

Como método de geração de dados da pesquisa qualitativa, a entrevista se faz pertinente em virtude do caráter dialógico presente. A entrevista foi organizada em três partes: a) contato 
inicial, b) a língua de sinais e c) a representação da língua. O objetivo deste artigo é apresentar a discussão teórica e analítica de duas perguntas inseridas nas etapas A e B. São elas "Como foi seu contato com a língua de sinais?” e "Para você, quem é o intérprete de Libras?”.

\section{Língua e linguagem: contribuições teóricas}

As primeiras pesquisas tendo a língua como objeto de uma abordagem científica surgiram com Ferdinand Saussure no início do século XX. Esses estudos forjaram as bases de um campo que viria a ser, posteriormente, conhecido como estruturalismo. Saussure é considerado o responsável pelo que se conhece hoje como linguística contemporânea, ou seja, a linguística como ciência da linguagem. Para esse campo de estudo, a linguagem foi categorizada em campos dicotômicos ${ }^{1}$, cujos conceitos são discutidos a partir de ideias contrapostas. Neste sentido, a dicotomia que nos interessa aqui é entre língua e fala.

Para Saussure (1969, p. 16), a linguística deve se preocupar em estudar a língua separadamente da fala, pois "é necessário colocar-se primeiramente no terreno da língua e tomála como norma de todas as outras manifestações da linguagem" (SAUSSURE, 1969, p. 16). Com esse conceito, ele entende que, como titulares de uma faculdade da linguagem, o ser humano somente tem como praticá-la através de uma condição natural, que é a língua.

A partir desse posicionamento, o linguista define seu objeto de pesquisa - a língua estudada em separado, como um sistema fechado em si mesma, que não considera as contribuições externas. As pesquisas estruturalistas apresentam a definição de língua como "um produto social da faculdade da linguagem e um conjunto de convenções necessárias, adotadas

${ }^{1}$ São outras dicotomias: significado $\mathrm{x}$ significante; sincronia $\mathrm{x}$ diacronia, paradigma $\mathrm{x}$ sintagma. (BAGNO, 2012, p. 45). 
pelo corpo social para permitir o exercício dessa faculdade nos indivíduos" e o que se entende a partir disto é que língua e fala não são interdependentes, pois a língua é "um todo por si" (SAUSSURE, 1969, p. 17). Ao considerar que a língua é social, adquirida, Saussure compreende que seu funcionamento não está relacionado com a consciência individual do falante.

Marcos Bagno (2012, p. 6o) critica a posição estruturalista do estudo da língua e explica que, nesse viés, a língua foi transformada em algo por si e em si. Ele afirma que

o estruturalismo transformou a língua numa 'coisa em si' - objetivo explicitado pelas últimas palavras do Curso de linguística geral [...] 'A linguística tem por único e verdadeiro objeto a língua considerada em si mesma e por si mesma'. [...] Renegando o falante e sua inserção numa comunidade, a linguística estrutural renegou no mesmo gesto o social, o cultural, o político e o ideológico - em suma, tudo que é caracteristicamente humano. (BAGNO, 2012, p. 6o. Grifos do autor)

A partir de outro entendimento, os pesquisadores Volóchinov e Medviédev integraram um círculo de intelectuais que se reunia em torno de Mikhail Bakhtin, na Rússia, entre 1895 e 1975. O grupo possui obras que colaboraram muito para o entendimento da língua enquanto fato social, vinculado ao falante. Os filósofos entendiam que a consciência individual do falante não poderia ser estudada separadamente da fala, pois tudo que se produz por meio da fala é construído historicamente e carrega as interferências recebidas nesse processo. Para Volóchinov (2017, p. 175), a língua só pode ser considerada um sistema de normas centrada em si mesma, se este for o "modus de existência da língua para cada um dos membros dessa coletividade linguística”. Portanto, uma concepção diferente do que apresentavam os defensores estruturalistas em que o processo comunicacional era entendido como uma via de mão única na qual o falante era visto como o sujeito ativo e o ouvinte, como o sujeito receptor do discurso.

Bakhtin, na obra Os gêneros do discurso (2016, p. 24), critica fortemente essa forma de concepção de estudo. Diz ele que ainda existem

na linguística burguesa ficções como o 'ouvinte' e o 'entendedor' (parceiros do 'falante', do fluxo da fala, etc.). Tais ficções dão uma noção absolutamente deturpada do processo complexo e amplamente ativo da comunicação discursiva. Nos cursos de linguística geral [...] aparecem com frequência Revista Investigações, Recife, v. 32, n. 2, p. 255 - 274, Dezembro/2019 
representações evidentemente esquemáticas de dois parceiros da comunicação discursiva - o falante e o ouvinte (o receptor do discurso); sugere-se um esquema de processos ativos de discurso no falante e de respectivos processos passivos de recepção e compreensão do discurso no ouvinte. Não se pode dizer que esses processos sejam falsos e que não correspondam a determinados momentos da realidade; contudo, quando passam ao objetivo real da comunicação discursiva eles se transformam em ficção científica. (BAKHTIN, 2016, p. 24. Grifos do autor).

Os estudos do Círculo preconizam que a língua é parte do enunciado, sendo este concreto, único, irrepetível e carregado de ideologia. Tais concepções demonstram a complexidade dos estudos advindos dessa teoria em contraponto com as teorias estruturalistas cujos pressupostos separavam a língua da fala. Os embates entre os estudiosos russos e os formalistas/objetivistas se dão pelo pensamento de que a língua é um sistema de regras abstratas que independe da realidade social e não considera que o sentido se faz a partir da interação entre sujeitos. (COSTA, 2017).

Ainda de acordo com as proposições defendidas, esse processo comunicacional no qual os estruturalistas acreditavam não corresponde ao efetivo processo de comunicação, pois seria uma posição abstrata em relação à compreensão responsivamente ativa do falante. Para o Círculo, essa abstração pode ser justificada por uma condição:

a de ser nitidamente compreendida apenas como abstração e não ser apresentada como fenômeno pleno concreto e real; caso contrário, ela se transforma em invenção. É exatamente o que acontece na linguística, uma vez que esses esquemas abstratos, mesmo não sendo apresentados diretamente como reflexo da comunicação discursiva real, tampouco são completados por alusões a uma maior complexidade do fenômeno real. (BAKHTIN, 2016, p. 26).

A partir dos estudos de Bakhtin e do Círculo, compreendeu-se, portanto, que a língua e a fala não poderiam ser vistas separadamente, pois ambas são carregadas de características que determinam as crenças e as formações sociais e culturais do falante. Passou-se, então, a compreender a língua como fato ideológico, que não se desvincula, de forma alguma, do que o sujeito discursivo acredita e o demonstra a partir da língua e da fala. 
Toda produção discursiva do falante está envolta em suas formações sociais, culturais, profissionais, familiares, entre outras áreas. Os seus argumentos são formados de discursos construídos historicamente, portanto o signo linguístico ${ }^{2}$ é atravessado por conteúdos ideológicos do mundo histórico social. (COSTA, 2017). Nesse ponto, o Círculo compreende que os enunciados concretos são inerentemente dialógicos e que a consciência do sujeito não é individual, mas formada pela coletividade social.

Pode-se compreender que o enunciado é vivo e "de natureza ativamente responsiva", o que significa dizer que todo enunciado requer uma resposta e, nesse processo, o falante passa a ser ouvinte e na troca de turno o ouvinte passa a ser o falante e assim sucessivamente. O processo de troca que ocorre mediante a inversão de turnos de fala traz para o discurso as formações ideológicas e sociais do sujeito falante e do sujeito respondente (BAKHTIN, 2016, p. 25).

Nessas concepções, os estudos do Círculo caminham no sentido de demonstrar que signo e ideologia estão intrinsecamente entrelaçados. Volóchinov (2017, p. 91) afirma que "sem signos não existe ideologia”, pois dominar o signo significa dominar a ideologia. Assim, chega-se no nível do signo, da palavra: o cerne de toda comunicação social.

Ao construir os estudos do campo da ideologia linguística, Volóchinov (2017, p. 100) conceitua que a palavra interior, ou seja, a palavra que serve como um "signo interior [...] sem ser plenamente expressa no exterior", é uma das questões de maior importância dentro da filosofia da linguagem, pois nenhum fenômeno ideológico pode acontecer sem a participação do discurso interior. O que o filósofo explica, em suma, é que a consciência individual já é ideológica por natureza e que em toda manifestação do falante ela vai aparecer.

A língua carregada de signos ideológicos marca e define, portanto, o processo comunicacional. O discurso, produzido a partir das escolhas de palavras do falante, é a representação das suas crenças, dos seus valores históricos construídos socialmente. Ao compreender que nenhum discurso é aleatório, a carga valorativa sobre a palavra passa a ser maior em uma sociedade ou menor em outra. A língua de sinais é um exemplo de disputa de valor linguístico em uma sociedade e, historicamente, vem buscando o seu reconhecimento social por meio de movimentos políticos e de representação de seus usuários majoritários, os surdos.

\footnotetext{
${ }^{2}$ Volóchinov compreende como signo "qualquer produto ideológico [...] que reflete e refrata outra realidade que se encontra fora dos seus limites", dessa forma, "tudo o que é ideológico possui significação: ele representa e substitui algo encontrado fora dele, ou seja, ele é um signo" (VOLÓCHINOV, 2017, p. 91).
}

Revista Investigações, Recife, v. 32, n. 2, p. 255 - 274, Dezembro/2019 


\section{Políticas linguísticas homogeneizadoras: o poder de uma língua só}

O Brasil nunca foi um país de uma língua só, pois habitavam aqui os indígenas que possuíam um idioma materno, próprio de cada comunidade, de cada região. Com a invasão dos portugueses, esses povos tiveram seu idioma roubado, usurpado à força de catequização e de dominação econômica. Havia aqui, aproximadamente, 1.078 línguas indígenas, o que mostra a pluralidade linguística existente. No entanto, ao longo de 500 anos, esse quantitativo reduziu para, aproximadamente, 170 línguas. É notório que a invasão portuguesa em terras brasileiras não visava apenas à exploração de reservas naturais, mas inserir os nativos em sua cultura e língua. Assim, inseriram políticas linguísticas homogeneizadoras que tinham por objetivo a eliminação de qualquer outro idioma que não fosse aquele da colônia portuguesa (OLIVEIRA, 2009).

A política linguística adotada pela Coroa era a de implementação, a qualquer custo, do idioma lusófono usando o que Gilvan Müller de Oliveira (2009) denomina de glotocídio, ou seja, o assassinato das línguas originais dos povos indígenas ou o seu deslocamento, substituição pelo português de Portugal. Não foram apenas os índios que sofreram com a aniquilação de seu idioma; os africanos, que foram escravizados pelos brancos, também foram vítimas de políticas linguísticas truculentas.

O poder conseguido pelo uso da língua ultrapassou séculos de dominação portuguesa alcançando seu apogeu máximo no reconhecimento oficial da língua do país invasor, em 1988, com a publicação da Constituição Federal. Seu artigo 13 diz que "a Língua Portuguesa é idioma oficial da República Federativa do Brasil" (BRASIL, 1988). Desde então, a Língua Portuguesa atua majoritariamente sobre todas as outras formas linguísticas existentes no país.

Essa atuação caracteriza o Brasil como um país monolíngue, ou seja, uma nação cujo idioma é único em todo território. O país reafirma esse posicionamento não apenas interna, mas também externamente, o que o insere no grupo de nações que possui o português como língua única oficial. Posicionamentos político-linguísticos como esses excluem quaisquer outras línguas, dialetos e culturas linguísticas existentes. Ao postular um único idioma brasileiro, o 
Estado exclui "as mais de cento setenta línguas nacionais indígenas, as mais de cerca de trinta línguas de imigração [e] a Libras" (CAVALCANTI; CÉSAR, 2007, p. 5o).

Ao legitimar um falante ideal e deslegitimar outro com a intenção de valorizar a língua do primeiro, cria-se uma sociedade cada vez mais segregada, com disparidades educacionais e econômicas. O que se tem no Brasil é a contradição entre o ensino da Língua Portuguesa nas escolas e o crescimento do desemprego, da desigualdade social (CAVALCANTI; CÉSAR, 2007).

Como mostram Cavalcanti e César (2007), as línguas minoritárias são aquelas apagadas pelo poderio da língua dominante, majoritária no país. Nesse escopo, encontra-se a Língua Brasileira de Sinais, língua da comunidade surda brasileira. Dada a prevalência da Língua Portuguesa sobre todas as outras manifestações linguísticas, a comunidade surda buscou pelo reconhecimento da Libras e obteve sucesso na homologação da Lei 10.436/2002.

Quanto à exclusão dos surdos, mesmo após o reconhecimento da língua, a grande maioria da população brasileira reconhece como língua apenas aquela que veio da Colônia. Os surdos continuam esquecidos e à margem da sociedade, uma vez que sua língua não é inserida nos espaços comunicacionais da sociedade ouvinte. As instituições de ensino superior foram os primeiros espaços a receberem a língua de sinais e a se debruçarem sobre suas particularidades linguísticas, sociais, identitárias e culturais, dando a ela alguma visibilidade social. (GESSER, 2009).

De todo o percurso histórico sobre as políticas homogeneizadoras apresentadas, há uma temática que precisa ser debatida e trazida à tona por pesquisadores do campo da Linguística, especialmente o da Linguística Aplicada: o mito do monolinguismo no Brasil. Cavalcanti (1999, p. 387) é enfática ao afirmar que "existe um mito de monolinguismo no Brasil" e explica que "esse mito é eficaz para apagar as minorias, isto é, as nações indígenas, as comunidades imigrantes e, por extensão, as maiorias tratadas como minorias, ou seja, as comunidades falantes de variedades desprestigiadas do português". O bilinguismo está presente em praticamente todos os países do mundo, mas é o monolinguismo que "representa a norma, é o monolinguismo que é a base para os estudos linguísticos", quando deveria ser o contrário (CAVALCANTI, 1999, p. 387).

Além disso, é fundamental considerar que os contextos monolíngues estão ao lado dos contextos bilíngues. Normalmente, os contextos de produção de línguas estigmatizadas são considerados assim por terem passado por um processo de apagamento da sua língua natural, ou da sua língua materna, mas continuam buscando pela sua ascensão. Não diferente das políticas de nacionalização do governo Vargas, as comunidades surdas também sofreram as Revista Investigações, Recife, v. 32, n. 2, p. 255 - 274, Dezembro/2019 
forças dessas atuações ostensivas. A língua foi proibida e restrita aos lares e os surdos obrigados a aprender a língua do país em sua modalidade oral.

A língua de sinais é a língua oficial da comunidade surda brasileira. Gesser (2009) explica que a Libras se originou da língua de sinais francesa, pois contam os registros que Dom Pedro II teria solicitado a vinda de um professor surdo francês ao Brasil - Ernest Huet -, em 1855, para instalar a primeira escola de surdos.

No entanto, a história da educação de surdos mostra um percurso de desvalorização da língua de sinais privilegiando a língua oral. As decisões sobre qual modalidade de língua a comunidade surda deveria usar partiram de um congresso realizado em Milão, no ano de 1880, que ficou marcado, entre outras deliberações, pela proibição do uso de sinais pelos surdos. No Congresso participaram representantes de destaque da sociedade da época. Lá foram discutidas as abordagens para a educação dos surdos a partir de três vertentes: da língua de sinais, do oralismo ou de um método denominado misto. Apesar de tais temáticas, a discussão maior se voltou para a língua de sinais e o oralismo. Com uma votação de 160 votos a 4, ficou proibido o uso da língua de sinais, substituindo-se então, os métodos já utilizados na educação de surdos que privilegiavam o uso dos sinais, por metodologias que praticavam técnicas de oralidade inclusive à força. Um personagem de destaque no Congresso foi Alexandre Graham Bell, que defendia que a surdez era uma aberração humana (GESSER, 2012).

Disto decorre que a língua dos surdos não possuía espaço para crescimento, nem para que os próprios usuários se conectassem e fizessem com que ela fosse propagada. Gesser (2009) explica que a história dos surdos foi de privação de uso da língua durante séculos, além da difícil relação dos surdos com a língua majoritária e também com a sociedade ouvinte. A língua de sinais era proibida em locais públicos, pois uma vez que esses sujeitos não tinham seus direitos reconhecidos, tampouco teriam possibilidade de utilizar uma língua própria em um espaço dominado por usuários de línguas orais.

Portanto, todo contexto de violação dos direitos de uso da língua da comunidade surda mostra a desvalorização pela qual passaram esses sujeitos durante séculos na sociedade ouvinte. Gesser (2012, p. 85) ainda explica que "os surdos eram vistos e representados como anormais por conta de sua deficiência auditiva e de sua suposta limitação para adquirir língua e desenvolver a fala oral. A surdez era tratada como uma aberração da raça humana na sociedade". Esse estereótipo se arrastou por anos a fio, fazendo com que a disputa de poder e de valor entre sujeitos surdos e ouvintes continue sendo tema de debates e pesquisas. 
Somente em 1960 a língua de sinais teve reconhecido seu status linguístico e, ainda hoje, mais de 50 anos depois, é preciso repetir e defender pesquisas sobre o tema para reafirmar a legitimidade dessa língua. O reconhecimento tem como marco os estudos linguísticos de William Stokoe, já que, antes disso, os sinais não eram vistos como uma língua verdadeira, que possuía a sua própria estrutura gramatical.

A primeira lei que reconheceu a língua brasileira de sinais foi a Lei 10.436, do ano de 2002. A lei dispõe sobre a língua de sinais e traz em seu artigo primeiro:

É reconhecida como meio legal de comunicação e expressão a Língua Brasileira de Sinais - Libras e outros recursos de expressão a ela associados.

Parágrafo único. Entende-se como Língua Brasileira de Sinais - Libras a forma de comunicação e expressão, em que o sistema lingüístico de natureza visualmotora, com estrutura gramatical própria, constituem um sistema lingüístico de transmissão de idéias e fatos, oriundos de comunidades de pessoas surdas do Brasil. (BRASIL, 2002).

Neste momento, portanto, após 161 anos da instalação da primeira escola para o ensino de sinais no Brasil, o país teve o reconhecimento da língua utilizada pelos surdos brasileiros. Este dado mostra que a política de homogeneização linguística praticada no país desde a invasão lusitana perdurou por mais de um século, passando por momentos de educação de surdos orientada por ouvintes e chegando até o seu efetivo reconhecimento legal.

Outro documento oficial que dá suporte à comunidade surda em prol da valorização de sua língua é o Decreto 5.626, do ano de 2005. Esse decreto regulamenta a Lei 10.436/2002 e o artigo 18 da Lei 10.098/200o, que trata da acessibilidade e da inclusão de pessoas com necessidades especiais. Nesse decreto, tem-se um maior detalhamento da importância da língua de sinais para os surdos e de políticas públicas de acesso e garantia de direitos. São regulamentados a inclusão da Libras como disciplina curricular nos cursos superiores, a formação dos professores e instrutores de Libras, a formação dos intérpretes de língua de sinais, o fomento e a difusão da Libras e a garantia de acesso dos surdos à saúde e à educação e o papel do poder público quanto à presença de intérprete de Libras. Esse decreto é considerado pela comunidade surda o documento de maior relevância desde a aprovação do primeiro documento 
oficial. A lei mais recente é a do reconhecimento da profissão de intérprete de Libras, que foi aprovada em $2010^{3}$.

A língua de sinais tem leis sólidas que dão total reconhecimento em âmbito nacional, no entanto, de nada adianta documentos oficiais se a sociedade não aceitar o idioma como língua oficial. Os surdos são uma parte expressiva da população mundial, com línguas de sinais reconhecidas no mundo todo, porém, carregam um ranço de segregação ao serem considerados diferentes do modelo de sujeito eurocêntrico. Gesser (2009) explica que os surdos foram proibidos de usar sua língua por séculos e quando desobedeciam eram castigados tendo as mãos amarradas. Tais castigos foram resquícios das orientações do Congresso de Milão, em 188o.

Dessa forma, com todo o histórico de apagamento da língua da comunidade surda brasileira, em conjunto com políticas educacionais monolíngues, essa discussão vem comprovar que, apesar de todo esforço empreendido, a língua de sinais ainda é uma língua minoritarizada por aqueles que constroem uma "imagem firmada de um país monolíngue onde, além da língua dita padrão, sequer uma variedade do português é reconhecida”. (CAVALCANTI, 1999, p. 394). Apresentamos abaixo o excerto analítico deste trabalho que busca discutir o lugar do intérprete dentro das escolas estaduais do estado de Minas Gerais a partir de uma entrevista qualitativa. Luana, que teve sua identidade real preservada por motivos éticos da pesquisa, atua como intérprete educacional desde 2016.

\section{Luana: “eu acho que o intérprete ainda não tem definição não...”}

A participante atua como intérprete na área educacional, tem formação em Pedagogia e pós-graduação em Libras. Além disso, possui experiência na área da surdez há sete anos na área pedagógica. A entrevista durou 49 minutos e a conversa foi fluida, sem intromissões e com respostas muito coerentes com as perguntas apresentadas.

\footnotetext{
${ }^{3}$ O projeto de Lei 9.382, apresentado na Câmara dos Deputados, em Dezembro de 2017, dispõe sobre o exercício profissional e condições de trabalho do profissional tradutor, guia-intérprete e intérprete de Libras, revogando a Lei ํㅡㄴ 12.319, de 1ํㅡㄹ de setembro de 2010.

Revista Investigações, Recife, v. 32, n. 2, p. 255 - 274, Dezembro/2019
} 
Luana inicia a entrevista relatando as primeiras experiências como intérprete de Libras em ambiente educacional. $\mathrm{O}$ excerto ${ }^{4}$ abaixo possui uma descrição detalhada do trajeto profissional realizado pela intérprete. Ela conta: aí deve ter uns dois anos... TRÊS anos... um ano eu peguei só um cargo... [...] de noite [...]... e ele era um surdo do... EJA... à noite... eu peguei de outubro até dezembro... depois no outro ano... ano passado... eu fiquei de manhã [...] na educação infantil.. e a tarde [...] no ensino fundamental um... eles tinham quatro cinco e sete anos... aí esse ano eu tô como intérprete... eu era intérprete [... de] um menino do segundo ano do ensino médio... lá em Três Corações... só que ele pediu pra mudar pra noite pra fazer o EJA porque ele já tem dezoito anos e ele não queria estudar... então ele mudou pra noite e pra mim ficou muito difícil acompanhar ele... ter que viajar à noite... e... desisti do cargo... e... tava aqui à tarde com [...] dois meninos do nono ano... [...] e... agora eu consegui de novo... acho que... foi semana passada... [...] que é uma menina do terceiro ano... só que ela é um pouco diferente... porque ela nasceu ouvinte... e tá perdendo audição agora... então ela fala... ela é oralizada... então é precisa de uma acompanhante não de uma intérprete... porque ela consegue entender o que o professor tá falando... [...]

É possível perceber que no período relatado Luana atuou em segmentos educacionais diferentes, assim como turnos e municípios também. Assim, as experiências vivenciadas nos espaços escolares se modificam muito, tanto como o relacionamento do profissional intérprete com o estudante surdo. O início da carreira como intérprete educacional, exclusivamente, se deu há três anos, no final do ano letivo, por um período em torno de três meses, conforme mostra o trecho: aí deve ter uns dois anos... TRÊS anos... um ano eu peguei só um cargo... [...] de noite [...]... e ele era um surdo do... EJA... à noite... eu peguei de outubro até dezembro... depois no outro ano... ano passado...

As mudanças de escolas, de turnos letivos, de segmentos e do próprio estudante surdo, são situações vivenciadas cotidianamente por esses profissionais que atuam na rede pública estadual em Minas Gerais. O governo mineiro, até o momento em que a pesquisa foi realizada, não havia efetivado, por concurso público, servidores para o cargo de Intérprete Educacional de

\footnotetext{
${ }^{4}$ Os trechos transcritos para análise foram incorporados ao texto da pesquisa e destacados em itálico, baseando as normas de transcrição para fatores não textuais em Dino Preti (2009). ... - qualquer tipo de pausa

[ ] - fala sobreposta

MAIÚSCULA - intensidade na palavra

: - prolongamento de vogal

/ - truncamento
}

Maiúscula inicial: somente nomes próprios

Revista Investigaçũes, Recife, v. 32, n. 2, p. 255 - 274, Dezembro/2019 
Libras. Sobre o cargo e a função deste profissional, Luana relata sobre o vínculo entre o intérprete e a escola ou entre o intérprete e o estudante surdo, pois o trabalho poderia ser continuado sem quebra do processo de ensino aprendizagem do estudante surdo. Ela diz: Achar intérprete é difícil... [...] então se você tivesse um vínculo... você continuaria com surdo... você continuaria seu trabalho... [...] você gasta um ano criando um trabalho com um surdo... no outro ano é outro intérprete..., portanto, pode-se analisar que a atuação em sala de aula para ela não é simples e superficial, mas uma função que demanda dedicação, pesquisa e muito estudo.

Pode-se compreender que, para ela, o ideal seria o intérprete seguir adiante com o surdo a cada aprovação no ano letivo. Para Volóchinov (2017, p. 195-196) as palavras são determinadas pelo seu contexto, assim, podem existir tantas significações quantos contextos de uso. Ao usar a palavra vínculo em sua resposta, Luana não a faz aleatoriamente, mas faz com o propósito de apresentar seus desejos profissionais e, também sua frustração por não conseguir dar continuidade aos trabalhos realizados nas escolas por onde passou.

Esta situação de mudança de intérpretes é recorrente, pois podem ocorrer alterações na situação de matrícula do estudante surdo como a mudança de escola, de cidade ou a evasão escolar. Desta forma, o profissional intérprete de Libras fica condicionado à matrícula de novos alunos surdos e à oferta de vagas para sua atuação nos espaços escolares. Nessa visão, este profissional é entendido como aquele que atua unicamente na sala de aula, porém, se houvesse um entendimento de que ele pode participar da instituição educacional como um todo, promovendo a inclusão e a difusão da Libras, seu espaço seria construído juntamente com a comunidade escolar e com a sociedade. Porém, estas possibilidades só se concretizam a partir de nomeação por concurso público.

Quando analisamos o excerto acima com o relato do seu trajeto profissional, percebemos que sua escolha em atuar nesse segmento vai ao encontro da demanda de vagas e da carência de profissionais, pois as escolas necessitam do intérprete para que o estudante surdo tenha acesso ao conhecimento escolarizado e não há quantidade suficiente de profissionais no mercado de trabalho. Trabalhar em duas ou três escolas ao mesmo tempo é uma escolha que pode ter como objetivo suprir a falta de profissionais e dar ao surdo o acesso à educação. É importante que se esclareça que não estamos fazendo julgamento, tampouco medindo o conhecimento de Luana em relação à língua de sinais, mas sim considerando a dificuldade de se atuar em segmentos educacionais distintos assim como as barreiras existentes para uma formação específica.

Ao perguntar como é a visão dos profissionais da educação, nas escolas por onde passou, em relação ao intérprete, aliada à atuação em sala de aula, Luana relata: eu percebo que os 
professores... tratam os surdos como uma criança... tipo... ESPECIA...L... incapaciTAda... não... não consegue... escrevER... não sabe se comuniCAr... é... visto como deficiente MESmo... e eles jogam a responsabilidade pra cima do intérprete... como se fosse NOSSOS alunos... e a gente fala... não... é... mas... você é o professor... você que tem que fazer adaptação... esse ano mesmo eu tive caso de um professor que falou que se ele tivesse que adaptar material pros meninos... ele podia ser mandado embora porque ele não é pago pra isso... coisas desse tipo... mas... por outro lado tem professor que nem precisou pedir... nem precisou explicar... traz material visuA...l... pede pros meninos... em vez de fazer... é... atividade escrita... fazer um cartAZ... então TEM professor que aJUda... que faz adaptação de material... e tem professor QUE... não tá nem aí... teve um outro professor que falou que... só de vim na escola ele [o surdo] já merece média... só pelo esfORço de vir... então vê que ele não tá nem ai com o aluno... acha que... ele não tá... incluído... ele tá só inserido na escola... é isso que eu sinto em relação aos... aos... surdos e em relação aos professores/... o problema tá mais nos professores do que no.... no aluno... ele tem capacidade normal... a diferença é que ele não ouve e usa outra língua... mas... os professores não conseguem entender isso....

O trecho nos apresenta uma realidade e traz pontos importantes para análise, começando pelo sentimento de frustração que acompanha o relato, a partir das escolhas lexicais para narrar as situações cotidianas vividas nas escolas. O trecho eu percebo que os professores... tratam os surdos como uma criança... tipo... ESPECIA...L... incapaciTAda... não... não consegue... escrevER... não sabe se comuniCAr... é... visto como deficiente MESmo... e eles jogam a responsabilidade pra cima do intérprete... como se fosse NOSSOS alunos... e a gente fala... não... você é o professor... mostra uma situação em que os professores não compreendem qual o papel do intérprete na sala de aula, assim como também não assumem a responsabilidade de ensinar o aluno surdo inserido na sala regular, e como afirma Luana jogam a responsabilidade pra cima do intérprete.

O posicionamento do educador regente ou do especialista em sala de aula perante alunos ouvintes e surdos deve ser o mesmo, resguardadas as formas distintas de aquisição do conhecimento. $\mathrm{O}$ aluno ouvinte tem acesso ao conhecimento por via oral-auditiva, o surdo pela via visual-espacial e se faz necessária a adaptação dos materiais utilizados nela como provas, trabalhos e da própria exposição dos conteúdos. O professor tem a responsabilidade de planejar as aulas, de escolher quais serão os conteúdos, de desenvolver o processo avaliativo, entre outras, já o intérprete, por conhecer o estudante surdo e a surdez "pode colaborar com o professor, sugerindo atividades, indicando processos que foram mais complicados, trabalhando em 
parceria, visando a uma inclusão mais harmoniosa dos alunos surdos”, no entanto, não é essa a realidade vivenciada por Luana (LACERDA, 2009, p. 35).

No excerto é isso que eu sinto em relação aos [...] professores/... o problema tá mais nos professores do que no.... no aluno... ele tem capacidade normal... a diferença é que ele não ouve e usa outra língua... mas... os professores não conseguem entender isso..., há um sentimento de tristeza e desapontamento em relação aos profissionais com os quais ela trabalha e a justificativa do que ela sente é dada aos professores, especialmente. O substantivo problema tem relação direta com o substantivo professores, mostrando que, mudando a forma de atuar, se dedicando a aprender a língua de sinais e conhecendo a cultura surda, os educadores podem alterar o cenário que se apresenta nas escolas regulares com surdos inseridos em salas de aula. Na visão de Luana, o estudante surdo possui capacidade normal de aprendizagem, a diferença é que ele não ouve e usa outra língua. Infelizmente, há profissionais que não compreendem isso e desrespeitam a possibilidade do surdo se desenvolver.

Os excertos analisados demonstram o verdadeiro sentimento que perpassa pela fala de Luana: a insatisfação. Os problemas enfrentados na atuação em sala de aula geram uma insegurança quanto ao futuro profissional dela e da categoria em função de posicionamentos governamentais. De acordo com o que entendem Mondada e Dubois (2003, p. 33), "uma categoria lexical impõe um ponto de vista [...] produzindo sentido a partir do contraste com as precedentes”, o que significa dizer que Luana, na construção do seu discurso narrativo, expôs seu ponto de vista por meio da palavra problema.

Ao encerrar sua construção discursiva sobre sua atuação em sala de aula, perguntei à

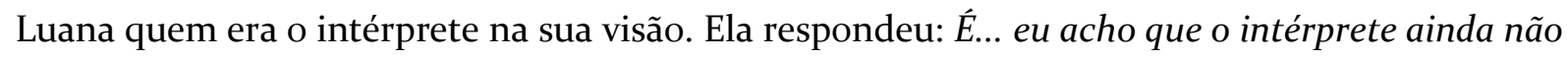
tem definição não... porque... primeiro... no Estado5 a gente é contratado como professor... não existe o NOSSO cargo... a gente vai pra sala de aula e muitas vezes a gente é TIrado de sala de aula... DEixa o aluno surdo ali sozinho pra poder substituir o professor que faltou... então... parece que não tem.... pare/... não tem comproMIsso com a nossa profissão... é:: acho que não tem como definir ainda... a gente tá numa LUta pra tentar fazer isso... mas... ninguém sabe o que é intérprete... ninguém sabe a nossa função... acha que a nossa função é.. é... uma... na verdade é outra... a gente nã/... enxerga a gente como babá de... de aluno e a gente NÃO é babá de aluno... acha que a gente tem que ficar responsável por adaptar material... mas a gente não PODE por mais que a gente queira... não é a nossa função... então é uma coisa que ainda não tá... não tá muito... muito clara... nem pros professores... nem pra educação... pro Estado... nem pra GENte... que a

\footnotetext{
${ }^{5}$ Escolas Estaduais de Minas Gerais.

Revista Investigaçũes, Recife, v. 32, n. 2, p. 255 - 274, Dezembro/2019
} 
gente fica em cima do muro... pra que lado que a gente vai? ... atende a escola... as vontades da escola... porque a gente recebe pela escola ou... faz aquilo que é melhor pro aluno... então... pra mim... o intérprete ainda não tá definido.

Luana respondeu de maneira incisiva à pergunta da entrevista. Ela afirmou: eu acho que o intérprete ainda não tem definição não. Em um primeiro momento, podemos recorrer às definições legais para compreender sua resposta. No Decreto 5.626/2005, não há definição sobre o profissional intérprete de Libras, apenas regulamenta como deve se dar sua formação em nível médio e superior. A Lei 10.436/2002, também não possui informações sobre o intérprete de Libras. Somente a Lei 12.319/2010 vai regulamentar o exercício a profissão do intérprete de Libras e apontar que "o tradutor e intérprete terá competência para realizar interpretação das 2 (duas) línguas de maneira simultânea ou consecutiva e proficiência em tradução e interpretação da Libras e da Língua Portuguesa" (BRASIL, 2010).

Dessa forma, a colocação de Luana vai ao encontro do que a legislação brasileira preconiza, ou seja, não há uma definição legal para quem seja o intérprete de Libras, apenas uma regulamentação das suas ações no exercício da profissão. No entanto, quanto ao que foi pensado como possibilidade de resposta à pergunta, não coube indefinição. Assim, ao analisar o excerto faz-se necessário destacar as justificativas apresentadas por Luana. Ela afirma que:
a) no Estado a gente é contratado como professor
b) não existe o NOSSO cargo
c) muitas vezes a gente é TIrado de sala de aula
d) ninguém sabe o que é intérprete
e) ninguém sabe a nossa função
f) enxerga a gente como babá de... de aluno

g) acha que a gente tem que ficar responsável por adaptar material

Os argumentos elencados acima são apresentados a partir do seu ponto de vista e das suas experiências na escola regular dentro da sala de aula, portanto, nos mostra que o Estado, mesmo que tenha publicado algumas legislações a respeito do tema, não conseguiu chegar em um consenso quanto às funções de um intérprete educacional. Ao relatar que no Estado a gente é contratado como professor e não existe o NOSSO cargo, Luana quer nos mostrar que o governo estadual de Minas Gerais ainda não criou o cargo para os intérpretes e que todos são contratados como professores de educação básica na função de intérprete de Libras. Ao dizer que muitas Revista Investiggações, Recife, v. 32, n. 2, p. 255 - 274, Dezembro/2019 
vezes são tirados da sala de aula para realizar substituição de professores ausentes, mais uma vez há demonstração de descaso com o profissional no ambiente escolar.

No momento em que Luana afirma que ninguém sabe o que é intérprete e ninguém sabe a nossa função, há um sentimento de abandono que emana das suas palavras, pois apresenta a ideia do profissional sozinho dentro da instituição, sem alguém que oriente o trabalho e dê o devido reconhecimento à função desempenhada. Assim, por não possuir uma chefia imediata ou um órgão que represente suas demandas, Luana desabafa: enxerga a gente como babá de... de aluno... acha que a gente tem que ficar responsável por adaptar material.

A atuação em sala de aula não é tarefa simples nem para o intérprete tampouco para o professor regente ou especialista que precisa lidar com a presença de um terceiro elemento em suas aulas. Sobre isso, Lacerda afirma que

a sala de aula tradicionalmente se constitui como um lugar no qual o professor ensina e a criança aprende. Com a entrada do ILS no espaço educacional, acrescenta-se um terceiro elemento que estará lá não só para interpretar da Libras para o português e do português para a Libras, mas para também mediar os processos discursivos entre professor e aluno, almejando a aprendizagem [...]. (LACERDA, 2009, p. 39).

A partir do ponto de vista da autora, é possível compactuar com a fala de Luana e suas justificativas quanto aos entraves que existem na prática da sala de aula. A inserção do profissional intérprete em uma sala de aula vai ocasionar mudanças exponenciais na rotina da sala, das aulas, dos estudantes e da própria escola em si. Há que se considerar que o envolvimento de todos colabora para que o trabalho seja desenvolvido da melhor maneira possível, buscando sempre o desenvolvimento e a aprendizagem dos estudantes ouvintes e, claro, dos surdos. 


\section{Considerações finais}

Após realizar a análise, percebemos como Luana se vê e se reconhece enquanto intérprete e usuária de língua de sinais. Pudemos compreender que permeia por sua fala um sentimento de insatisfação pela condição na qual o surdo é inserido na escola, assim como sua condição de profissional intérprete de Libras, em um ambiente despreparado, justamente por não ter sido previamente organizado para receber os alunos surdos oriundos das escolas especiais.

Luana nos mostrou que os espaços de atuação dos intérpretes precisam se adequar às necessidades dos profissionais e às demandas dos estudantes atendidos. Em seu discurso há um sentimento de tristeza em função do descaso por parte dos governantes, especialmente do Governo de Minas Gerais, realidade a qual pertence. No entanto, seu discurso mostra uma profissional de excelência, dedicada e preocupada com a aprendizagem dos estudantes surdos os quais acompanha e já acompanhou. Como militante em prol da comunidade surda, reconhece que a Libras é a língua que a comunidade ouvinte deve respeitar e aprender para usar na comunicação com os surdos.

Voltamos, assim, aos objetivos deste artigo e concluímos que o lugar desse profissional ainda não está definido tampouco estão estabelecidas suas funções dentro das escolas do sul do estado de Minas Gerais, dessa forma, vemos que a atuação se dá de forma intuitiva ainda que sempre busque privilegiar o surdo.

\section{Referências}


BAGNO, M. A caverna implodida: por uma concepção não platônica de língua. In: BAGNO, M. Gramática pedagógica do português brasileiro. São Paulo, Parábola, p. 37-79, 2012.

BAKHTIN, M. (V.) Marxismo e filosofia da linguagem: problemas fundamentais do método sociológico na ciência da linguagem. Trad. LAHUD, M e VIEIRA, Y. F. 13.ed. $1^{\mathrm{a}}$ reimpressão. São Paulo: Hucitec, 2012. 203 p.

. Os gêneros do discurso. BEZZERA, P. (organização, Tradução, Posfácio e Notas da edição russa: BOTCHAROV.S). São Paulo: Editora 34, p. 11-69, 2016.

BONI, V; QUARESMA, S. J. Aprendendo a entrevistar: como fazer entrevistas em Ciências Sociais. Revista Eletrônica dos Pós-Graduandos em Sociologia Política da UFSC. v. 2, no 1 (3), p. 68-8o, jan/jul., 2005.

BRASIL. Casa Civil. Constituição da República Federativa do Brasil. Brasília: 1988. Disponível em: <http://www.planalto.gov.br/ccivil o3/constituicao/constituicao.htm>. Acesso em: 18 de jun. de 2018.

BRASIL. Casa Civil. Lei n.o ${ }^{10.436}$. Dispõe sobre a Língua Brasileira de Sinais - Libras e dá outras providências. Brasília: 2002. Disponível em: <https://www.planalto.gov.br/ccivil 03/leis/2002/l10436.htm>. Acesso em: o1 de set de 2017.

BRASIL. Casa Civil. Decreto n.ํㅜ 5.626. Regulamenta a Lei n.ํㅜ 10.436, de 24 de abril de 2002, que dispõe sobre a Língua Brasileira de Sinais - Libras, e o art. 18 da Lei n.o 10.098 , de 19 de dezembro de 2000. Brasília: 2005. Disponível em: <https://www.planalto.gov.br/ccivil 03/Ato20042006/2005/Decreto/D5626.htm>. Acesso em: o1 de set de 2017 .

BRASIL. Casa Civil. Lei n.ำ 12.319. Regulamenta a profissão de Tradutor e Intérprete da Língua Brasileira de Sinais - LIBRAS Brasília: 2010. Disponível em: <http://www.planalto.gov.br/ccivil 03/ at02007-2010/2010/lei/l12319.htm>. Acesso em: 20 de set de 2017 .

BRASIL. Câmara dos Deputados. Projeto de Lei 9.382. Dispõe sobre o exercício profissional e condições de trabalho do profissional tradutor, guia-intérprete e intérprete de Libras, revogando a Lei no 12.319, de $1^{\circ}$ de setembro de 2010. 2017. Disponível em: $<$ http://www.camara.gov.br/proposicoesWeb/prop mostrarintegra? codteor=1634551>. Acesso em: $18 \mathrm{de} \mathrm{dez} \mathrm{de} 2018$.

CAVALCANTI, M. Estudos sobre educação bilíngüe e escolarização em contextos de minorias lingüisticas no Brasil DELTA, vol. 15, no especial, p. 385-417, 1999. Disponível em: <http://www.scielo.br/pdf/delta/v15nspe/4023.pdf $>$. Acesso em 18 de jun. de 2018. 
CAVALCANTI, M.; CÉSAR, A. L. Do singular para o multifacetado: o conceito de língua como caleidoscópio. In.: BORTONI-RICARDO, S. M; CAVALCANTI, M. (Orgs). Transculturalidade, Linguagem e Educação. Campinas, SP: Mercado das Letras, p. 45-66, 2007.

COSTA, L. R. A questão da ideologia no Círculo de Bakhtin e os embates no discurso de divulgação científica da revista Ciência Hoje. Cotia: Ateilê/Fapesp, Vol. 1. p. 89-95; 132-138; 152-156, 2017.

GESSER, A. LIBRAS? Que língua é essa?: crenças e preconceitos em torno da língua de sinais e da realidade surda. São Paulo: Parábola, 2009. 87 p.

O ouvinte e a surdez: sobre ensinar e aprender a LIBRAS. São Paulo: Parábola, 2012. 187

p.

LACERDA, C. B. F. de. Intérprete de Libras em atuação na educação infantil e no ensino fundamental. Porto Alegre: Mediação, 2009. 96 p.

MONDADA, L.; DUBOIS, D. Construção dos objetos de discurso e categorização: uma abordagem dos processos de referenciação. In: CAVALCANTE, M. M.; RODRIGUES, B. B.; CIULLA, A. Referenciação. São Paulo: Contexto, 2003.

OLIVEIRA, G. M. de. Brasileiro fala português: monolinguismo e preconceito linguístico. Revista Linguasagem. 11 ed. UFSCAR: 2009. Disponível em: <http://www.letras.ufscar.br/linguasagem/edicao11/artigo12.pdf $>$. Acesso em o5 de set de 2017. SAUSSURE, F. Objeto da linguística. In: SAUSSURE, Ferdinand. Curso de linguística geral. São Paulo, Cultrix, p. 15-25, 1969.

VOLÓCHINOV, V. N. (Do círculo de Bakhtin). Marxismo e filosofia da linguagem: problemas fundamentais do método sociológico na ciência da linguagem. Org., Trad., Notas de GRILLO, S. e AMÉRICO, E. V. São Paulo: Editora 34, p. 91-102; 173-200, 2017.

\footnotetext{
* Mestre em Letras, área de concentração Linguística, pela Universidade Vale do Rio Verde (UninCor).
} 